\title{
PERFORMANCE COMPARISON OF PID CONTROLLER AND FUZZY LOGIC CONTROLLER FOR WATER LEVEL CONTROL WITH APPLYING TIME DELAY
}

\author{
Fuad ALHAJ OMAR \\ Zonguldak Bülent Ecevit University, Department of Electric and Energy, Zonguldak, TURKEY \\ fuad.a@beun.edu.tr
}

(Geliş/Received: 31.07.2021; Kabul/Accepted in Revised Form: 06.09.2021)

\begin{abstract}
Liquid level control is a system often found in most industrial facilities. Usually, embedded control systems are used, as these systems play an increasingly important role in control engineering. Time delay is one of the most important parameters which affects the control systems performance. This study aims to design a water level control system in MATLAB/ Simulink environment using the proportional integral derivative (PID) controller and Fuzzy Logic (FL) controller and then to investigate the effect of the time delay on their performance. The two control systems were tested and compared in terms of performance, with and without applying a time delay. The study highlights the application of two types of delays (distributed time delay and discrete-time delay) to the output of the built-in control system and discusses the results. The results showed that the FL controller is better than the PID controller in terms of stability and performance. Although the rise time of both controllers was almost the same, the FL controller showed higher performance in terms of overshoot and settling time. While the overshoot for the PID controller was $9.33 \%$, it did not appear when using the FL controller. Moreover, the settling time of the PID controller was 10 seconds, while the FL controller took only 8.6 seconds to achieve stabilization. As a result, the FL controller has demonstrated the ability to eliminate the overshoot problem that appears when using PID controllers and stabilize faster.
\end{abstract}

Key Words: Embedded control system, PID controller, FL controller, Distributed time delay, Discrete-time delay.

\section{Zaman Gecikmesi Uygulanarak Su Seviyesi Kontrolü İçin PID Kontrolör ve Bulanık Mantık Kontrolörünün Performans Karşılaştırması}

ÖZ: Sıvı seviye kontrolü, çoğu endüstriyel tesiste sıklıkla bulunan bir sistemdir. Genellikle gömülü kontrol sistemleri kullanılır, çünkü bu sistemler kontrol mühendisliğinde giderek daha önemli bir rol oynar. Zaman gecikmesi, kontrol sistemlerinin performansını etkileyen en önemli parametrelerden biridir. Bu çalışma, MATLAB/Simulink ortamında orantılı integral türev (PID) denetleyicisi ve Bulanık Mantık (FL) denetleyicisi kullanarak bir su seviyesi kontrol sistemi tasarlamayı ve ardından zaman gecikmesinin performanslarına etkisini araştırmayı amaçlamaktadır. İki kontrol sistemi, zaman gecikmesi uygulanarak ve uygulanmadan performans açısından test edilmiş ve karşılaştırılmıştır. Bu çalışma, kontrol sisteminin çıkışına iki tür gecikmenin (dağıtılmış zaman gecikmesi ve ayrık zaman gecikmesi) uygulanmasını vurgular ve sonuçları tartışır. Sonuçlar, FL kontrolörünün kararlılık ve performans açısından PID kontrolörden daha iyi olduğunu göstermiştir. Her iki kontrolörün yükselme süresi hemen hemen aynı olmasına rağmen, FL kontrolör aşım ve yerleşme süresi açısından daha yüksek performans göstermiştir. PID kontrolörü için aşım \%9,33 iken, FL kontrolörü kullanılırken görülmüyordu. Ayrıca, PID kontrolörünün yerleşme süresi 10 saniye iken, FL kontrolörünün stabilizasyonu sağlaması sadece 8,6 
saniye sürmüştür. Sonuç olarak, FL kontrolörü, PID kontrolörleri kullanılırken ortaya çıkan aşma sorununu ortadan kaldırma ve daha hızlı stabilize etme yeteneğini göstermiştir.

Anahtar Kelimeler: Gömülü kontrol sistemi, PID kontrolörü, FL kontrolörü, Dă̆ıtılmış zaman gecikmesi, Ayrık zaman gecikmesi.

\section{INTRODUCTION}

Control systems are an essential part of the control process in laboratories, industrial facilities, and many other electronic systems. Therefore, the process of developing these systems has been an area of interest to researchers and specialists in order to meet the new needs of control systems and solve problems that the currently used systems still suffer from (Yang 2012). Embedded control systems are systems in which control algorithms are implemented in real-time by using feedback. Embedded control systems are the synthesis between digital techniques and control theory. Every electrical or mechanical system that contains a control unit and is implemented depending on a digital processor is called an embedded system (Petkov et al., 2018).

The control of the liquid level in the tank is an important aspect widely used in industrial processes (Al Tahtawi and Marsya 2020) (Thakur et al., 2015). In order to obtain high-quality products, the liquid level in the tank must be maintained at a specific point. Since the parameters of the industrial plant change frequently, maintaining the water level at a specific point is difficult (Shahid et al., 2016). For this reason, the liquid level control system is considered a complex system that traditional control methods are insufficient to deal with (Yumurtacı and Verim, 2020). Thus, it is necessary to employ an embedded control system capable of adjusting the liquid level at its set point and which is not affected by the variable disturbances in the plant (Thakur et al., 2015). In such applications, the PID controller is one of the most widely used controllers. By adjusting the parameters of the PID controller according to the nature of the system, the best performance can be obtained (Mukhtar et al., 2019). However, since PID parameters tuning is a challenging task, effective control is difficult to obtain (George and Ganesan, 2020). Therefore, using the FL controller was suggested as a solution to overcome these problems (Dinesh et al., 2015). Many studies made a comparison between the performance of the FL controller and the PID controller in terms of maintaining the level of liquid in a tank, and they found that the FL controller has better stability, smaller overshoot, and fast response (Shahid et al., 2016) (Thakur et al., 2015) (Prusty et al., 2014) (Yahya et al., 2020). Others tested the performance of PID and FL controllers in coupled tank systems and found that FL controller has better performance, and it is a good option for real-world applications (Kumar and Nagpal, 2017). (Shaikh and Kulkarni, 2019) explained that the integration of the FL controller with the PID controller gives a smooth steady-state response without any oscillations or overshoots. The settling time is also improved. (Chen 2021) showed that both PID and FL controllers can control the liquid level to remain stable, but with using the FL controller, the system has better dynamic quality, longer stable response time and higher precision. However, the previous studies did not report any testing of the two control systems to adjust the liquid level in a tank with a time delay applied.

This paper focuses on designing an embedded control system to control the water level in the tank using a PID controller and a FL controller. First, the two controllers will be tested and compared in terms of performance without a time delay being applied. Then the system performance will be tested with a time delay applied to the system output. Two types of time delays will be applied to the system output:

1. Distributed Time Delay.

2. Discrete-Time Delay.

To conduct the design, conduct tests and draw conclusions, MATLAB software will be used, as it provides an environment that meets all the needs of the study. 


\section{MATERIAL AND METHOD}

\subsection{Modeling the system}

The system adopted in this research is a water tank shown in Figure 1, where the water level in the tank will be controlled between 0.5 and 1.5 by controlling the valve. The following mathematical equations for the system (water tank) were deduced and modelled using MATLAB.

$$
\begin{aligned}
& q_{\text {in }}(t)=Q_{v} \text { Valve }(t) \\
& q_{\text {out }}(t)=\alpha \text { vout } \\
& \text { vout }=\sqrt{2 g h(t)}
\end{aligned}
$$

Equation (1) represents the flow rate of water entering the tank.

$Q_{v}$ : The average pump velocity.

$\operatorname{Valve}(t)$ : valve settings.

Equation (2) represents the flow rate of the water leaving the tank.

$\alpha$ : tank hole diameter.

Vout: the velocity of the water flow.

Equation (3) represents the velocity of the water leaving the tank, where Bernoulli's law was used. $g$ : gravitational acceleration.

$h(t)$ : height of the tank.

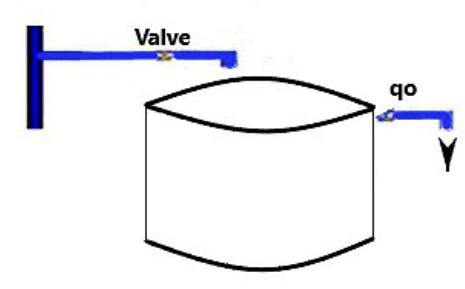

Figure 1. Tank circuit

\subsection{Work methodology}

The working mechanism depends on calculating the error value, which is the difference between the actual value and the desired value. Based on the error value, the controller will adjust the valve to maintain the tank level between 0.5 and 1.5. Figure 2 shows a block diagram of the algorithm.

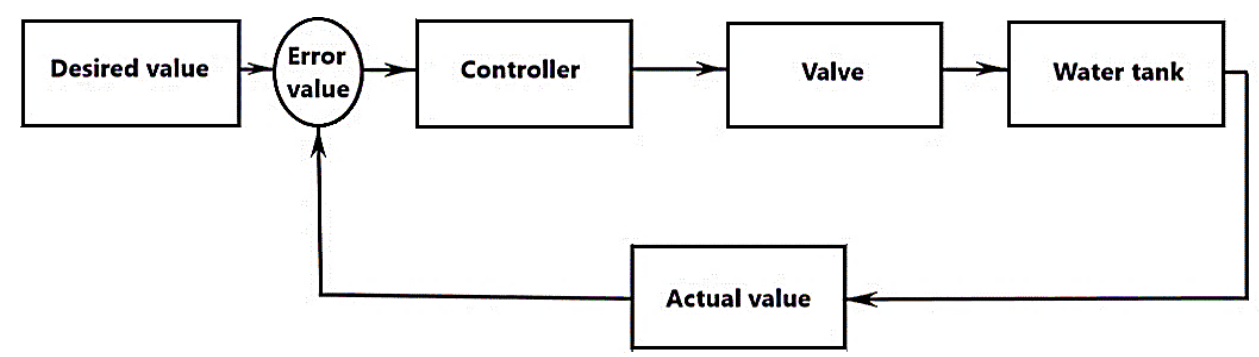

Figure 2. Block diagram of the valve control algorithm 


\subsection{PID controller}

This controller made a qualitative leap in improving the performance of control loops, as it provides good results in terms of response time and control accuracy (Torres et al., 2006). It is also distinguished in terms of capabilities due to the diversity of the elements working within this controller. There are proportional controllers, proportional integral controllers, and others to provide the needs of the control system (Muresan et al., 2019). To date, it is still the most preferred type of control system, especially after the introduction of new concepts, such as the synthesis of adaptive controllers (Sreepradha et al., 2016). However, the increasing complexity of control systems required the development of new control mechanisms such as artificial neural networks and FL, which have helped achieve many applications with remarkable success (Kamala et al., 2012). The block diagram of the PID controller is shown in Figure 3. Where $\mathrm{Kp}$ is the proportional gain, $\mathrm{Ki}$ is the integral gain, and $\mathrm{Kd}$ is the derivative gain (Perng et al., 2014).

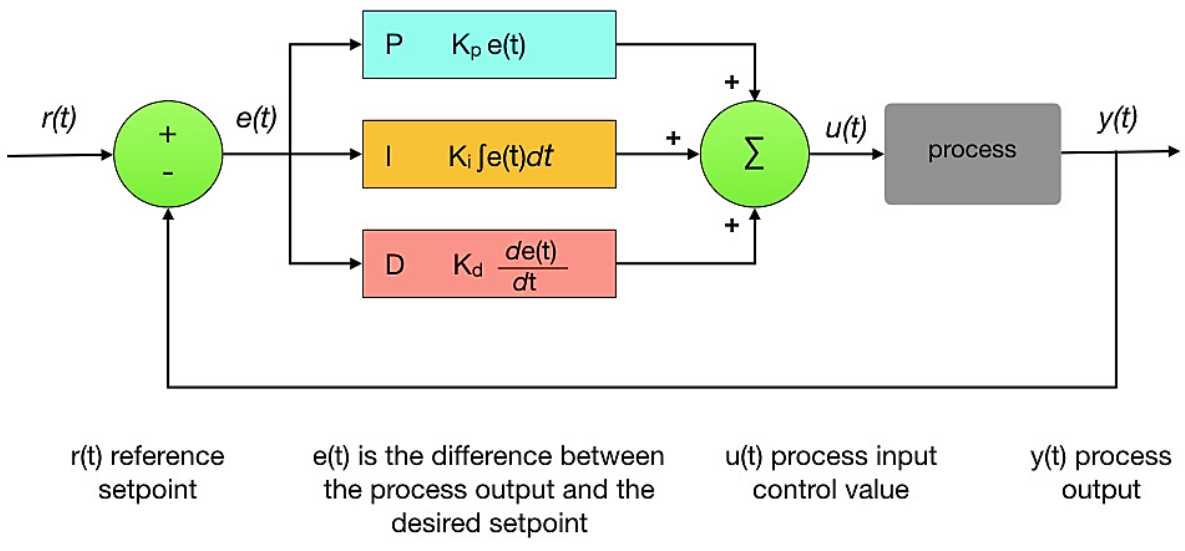

Figure 3. PID Controller

\subsubsection{Determining the parameters of the PID controller}

PID controller parameters can be determined based on the Ziegler Nichols method, which depends on the response curve of the system shown in Figure 4 (Meshram and Kanojiya, 2012). This method starts making the system unstable by increasing the proportional gain and zeroing the differential and integrative gains. The method then backs off the proportional gain a predetermined amount and sets differential and integrative gains as a function of the oscillation frequency (Ellis, 2012). The parameters of the PID constants can be calculated according to Table (1).

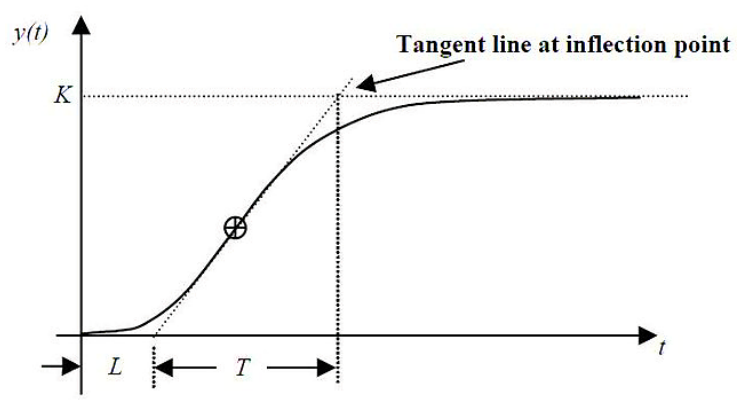

Figure 4. Response Curve of Ziegler-Nichols method 
Table 1. PID controller parameters

\begin{tabular}{|c|c|c|c|}
\hline $\begin{array}{c}\text { Type of } \\
\text { controller }\end{array}$ & $K_{p}$ & $T_{i}$ & $T_{d}$ \\
\hline $\mathrm{P}$ & $\mathrm{Ku}$ & - & - \\
\hline $\mathrm{PI}$ & $0,9 \mathrm{Ku}$ & $3 L$ & - \\
\hline $\mathrm{PID}$ & $1.2 \mathrm{Ku}$ & $2 L$ & $0.5 L$ \\
\hline
\end{tabular}

Where:

$K_{u}$ : ultimate gain.

$K_{p}$ : the proportional gain.

$T_{i}$ : the controller's integrative time constant.

$T_{d}$ : the controller's differential time constant.

$L$ : delay time.

\subsection{FL controller}

FL is an approach to computing based on "degrees of truth" rather than the usual "true or false" (1 or 0) Boolean logic on which the modern computer is based (Thompson et al., 2012).

FL is based on fuzzy set theory, which is a generalization of classical set theory, which means that classical sets are a special case of fuzzy sets. In classical sets, the element either belongs to the set or does not at all, while in fuzzy sets, the same element can belong to several sets at the same time (Plerou et al., 2016). The FL controller consists of four main components shown in Figure 5: the Fuzzification, the Rules, the Inference Engine, and the Defuzzification (Boada et al., 2005).

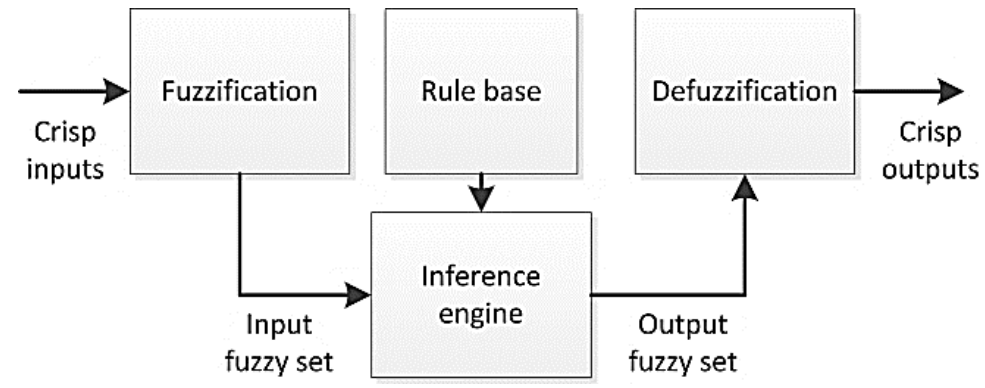

Figure 5. FL Controller

\section{RESULT AND DISCUSSION}

\subsection{Designing the PID controller}

According to Table (1), the values of the parameters of the PID controller were chosen as follows: $\mathrm{Kp}=5, \mathrm{Ki}=0, \mathrm{Kd}=1$.

The system controlled by the PID controller was built in the MATLAB/ Simulink environment as shown in Figure 6. The result of controlling the water level in the tank showed that there is a slight overshoot in the output signal as shown in Figure 7. 


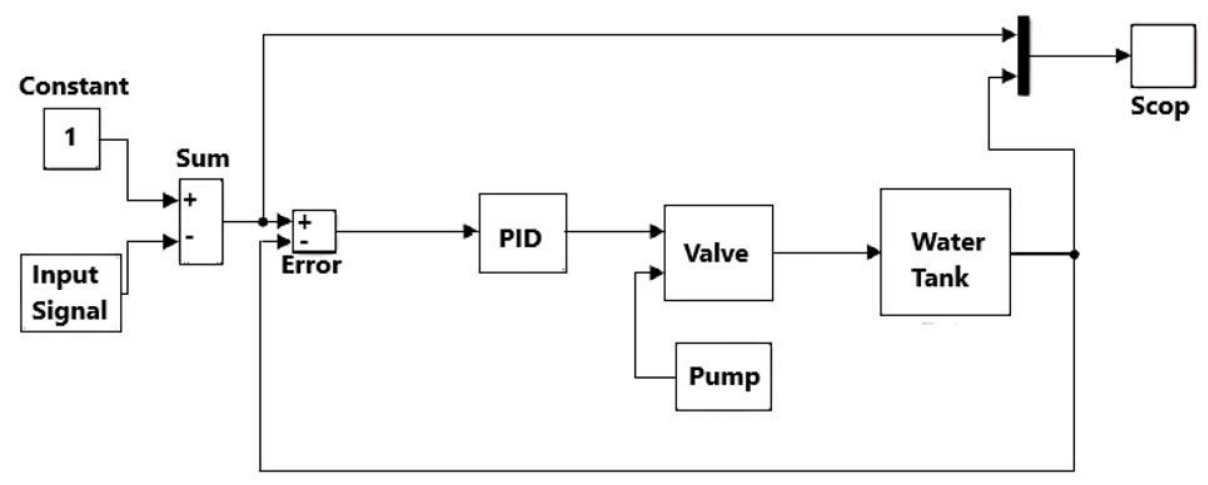

Figure 6. Water tank system with PID controller

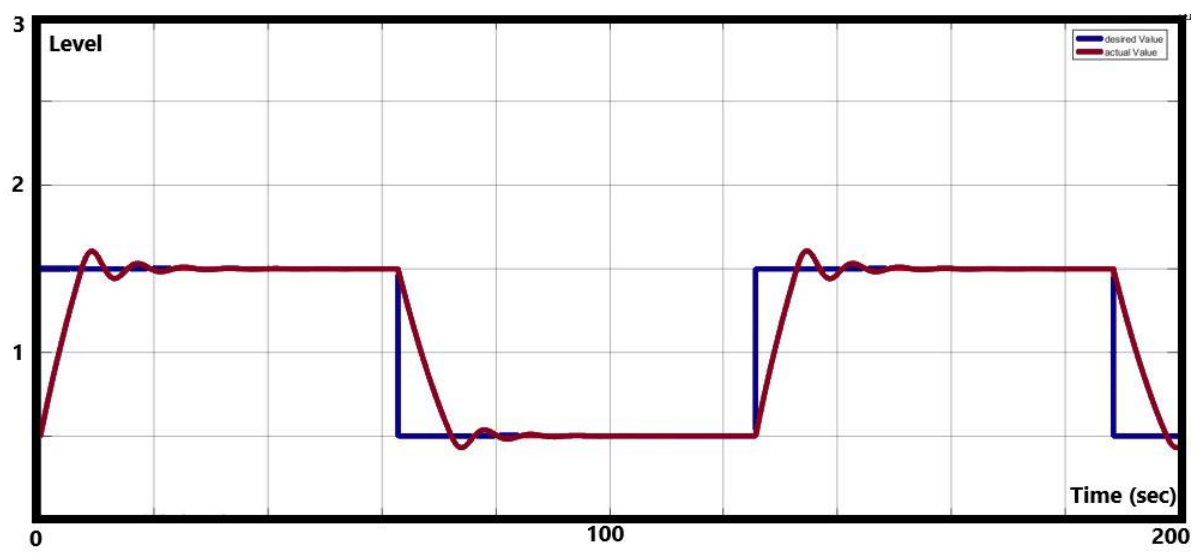

Figure 7. The result of controlling the water level in the tank using the PID controller

\subsection{Designing the FL controller}

The FL controller was built in the MATLAB environment and designed to adjust the water level in the tank by controlling the valve. The FL controller, which was designed as shown in Figure 8, consists of two inputs:

1. Water level (Error).

2. The rate of change of the output.

The output is the valve settings.

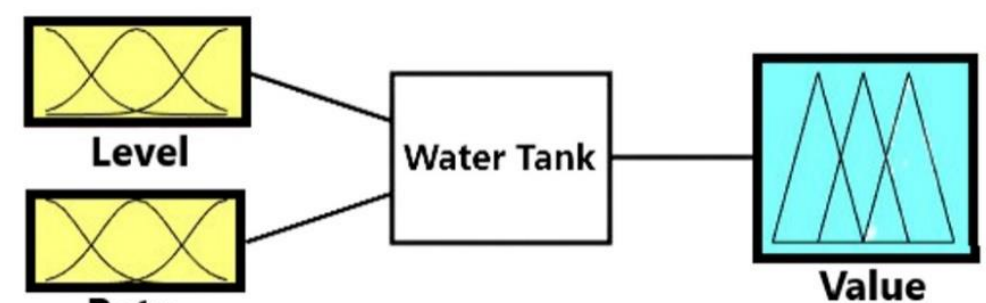

Rate

Figure 8. The FL built in MATLAB 
Figure 9 shows the membership function of the first input variable of the FL controller. The input variable within the range $[-1,1]$ has been divided into three membership functions with a Gaussian distribution:

1. High within the range $[-1,-0.3]$.

2. Okay within the range $[-0.3,0.3]$.

3. Low within the range $[0.3,1]$.

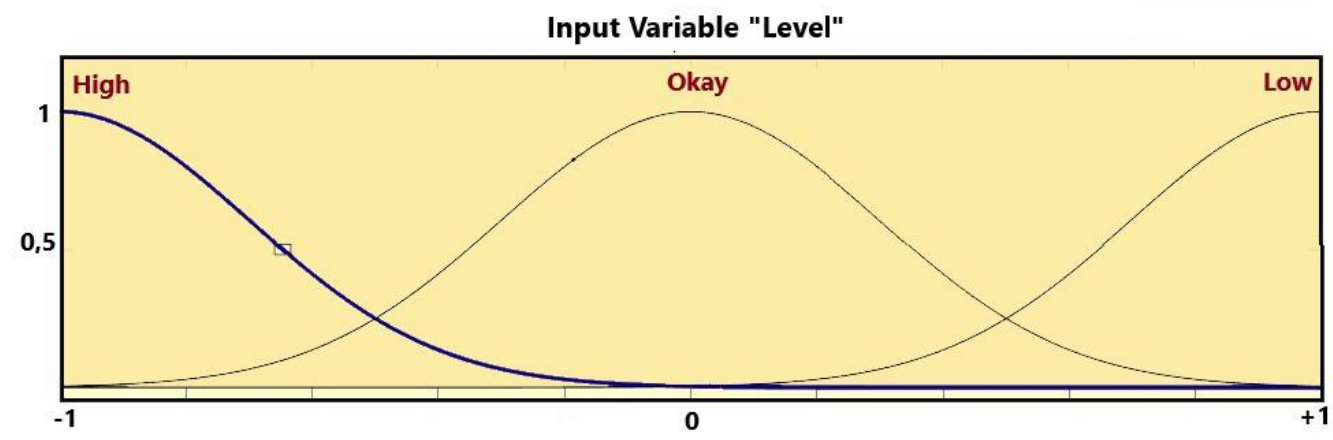

Figure 9. Membership function of the first input variable of the FL controller

Figure 10 shows the membership function of the second input variable of the FL. The input variable within the range $[-0.1,0.1]$ has been divided into three membership functions with a Gaussian distribution:

1. Decreasing within the range $[-0.1,-0.03]$.

2. No-change within the range $[-0.03,0.3]$.

3. Increasing within the range $[0.03,0.1]$.

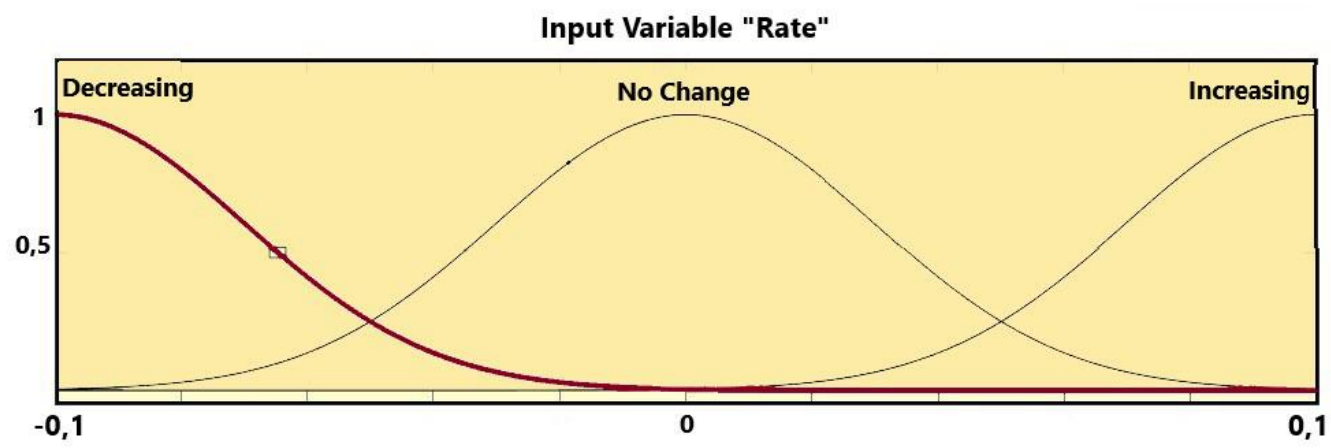

Figure 10. Membership functions of the second input variable of the FL controller

Figure 11 shows the membership functions of the FL controller's output variable. The variable within the range $[-1,1]$ was divided into five membership functions with a trigonometric distribution:

1. Fast close within range $[-1,-0.9,-0.8]$.

2. Slow close within the range $[-0.6,-0.5,-0.4]$.

3. No-change within the range $[-0.1,0,0.1]$.

4. Slow open within the range $[0.2,0.3,0.4]$.

5. Fast open within range $[0.8,0.9,1]$. 
Output Variable "Valve"

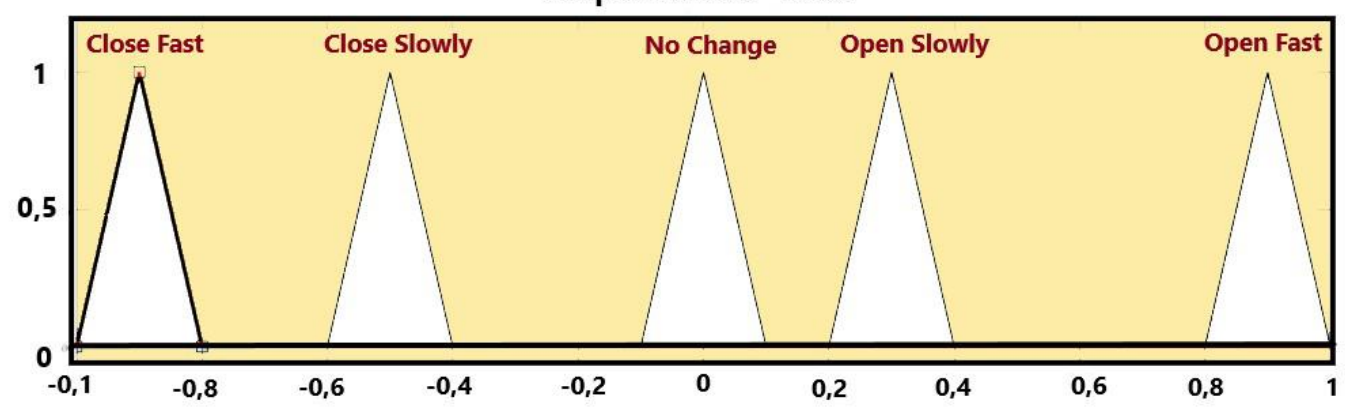

Figure 11. Membership functions of the FL controller's output variable

Five rules were used to control the valve position to maintain the water level in the tank as shown in Table 2.

Table 2. Control rules for FL controller

\begin{tabular}{|l|l|}
\hline \multicolumn{1}{|c|}{ Rule } & \multicolumn{1}{c|}{ Control action } \\
\hline If (Level is High) & then (The valve closes fast) \\
\hline If (Level is Okay) & then (The valve does not change) \\
\hline If (Level is Low) & then (The valve opens fast) \\
\hline If (Level is Okay) and (Rate is increasing) & then (The valve closes slowly) \\
\hline If (Level is Okay) and (Rate is Decreasing) & then (The valve opens slowly) \\
\hline
\end{tabular}

The system controlled by the FL controller was built in MATLAB/ Simulink environment as shown in Figure 12. The result of controlling the water level in the tank showed that the overshoot problem was solved by using the FL controller, as shown in the output signal in Figure 13.

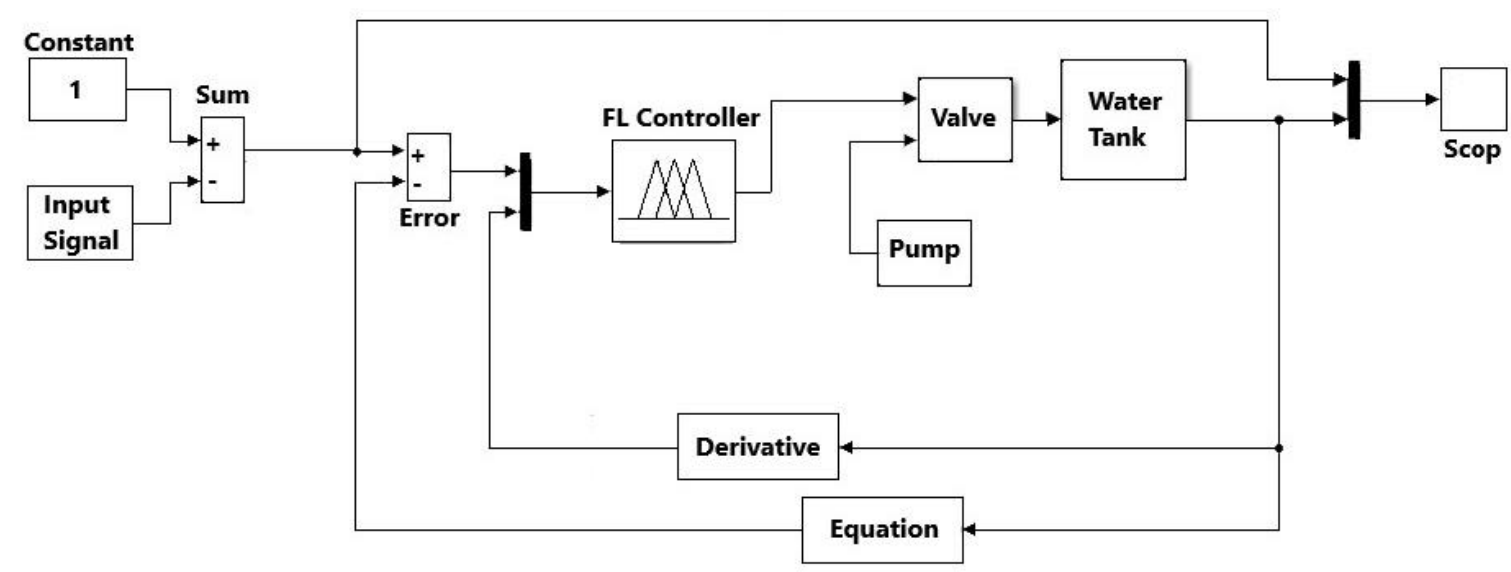

Figure 12. Water tank system with FL controller 


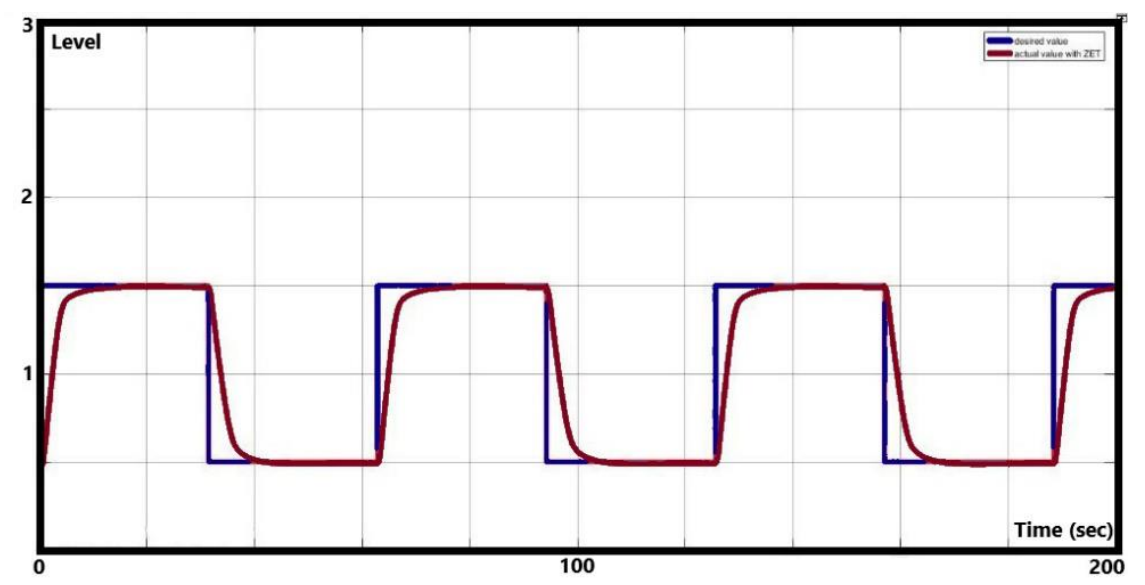

Figure 13. The result of controlling the water level in the tank using the FL controller

To analyze the results obtained, the comparison of transient responses such as rise time, overshoot and settling time for both controllers are shown in Table 3. In terms of settling time and overshoot, the FL controller showed superior performance compared to the PID controller. While the overshoot using the PID controller was $9.33 \%$, it did not appear with the use of the FL controller. Similarly, the settling time using the PID controller was $10 \mathrm{sec}$, while by using the FL controller was $8.6 \mathrm{sec}$. On the other hand, the rise time values were approximately the same, with the PID controller taking 4 seconds while the FL controller taking 4.1 seconds.

Table 3. Comparison of transient responses of PID \& FL controllers

\begin{tabular}{|c|c|c|c|}
\hline Controller & rise time (sec) & Overshoot $(\%)$ & settling time (sec) \\
\hline PID & 4 & 9.33 & 10 \\
\hline FL & 4.1 & Not present & 8.6 \\
\hline
\end{tabular}

\subsection{Control of the system with a time delay}

The two controllers were tested with a system output delay, in which two types of time delays (Distributed Time Delay \& Discrete-Time Delay) were applied.

\subsubsection{Distributed time delay}

The change of the distributed delay output is proportional to the difference between the input and the output and the proportionality constant $(1 / \Delta)$, and is determined by the following relationship (Beretta and Breda, 2016):

$$
\frac{d}{d x} y(t)=\frac{1}{\Delta}[x(t)-y(t)]
$$

Depending on the system output (water tank):

$$
h^{\prime}(t)=\frac{1}{\Delta}(q \text { in }-q o u t)=\frac{1}{\Delta}(q \text { in }-\alpha \sqrt{2 g h(t)})
$$

$\alpha$ : Tank hole diameter. 
qin: The water flow rate into the tank.

qout: The water flow rate from the tank.

Assuming:

$h^{`}=y^{\prime}, h=y, k=\sqrt{2 g}$

The equation will be as follows:

$y^{\prime}=\frac{1}{\Delta}(q i n-\alpha k \sqrt{y})$

$y^{\prime}=\frac{q i n}{\Delta}-\frac{\alpha k}{\Delta} \sqrt{y}$

$y^{`}+\frac{\alpha k}{\Delta} \sqrt{y}=\frac{q i n}{\Delta}$

This is a first-order differential equation that can be solved by Laplace transform:

$L\left\{y^{\prime}\right\}+\frac{a k}{\Delta} L\{\sqrt{Y}\}=L\left\{\frac{q i n}{\Delta}\right\}$

$s Y(s)-y(0)+\frac{\alpha k}{\Delta} \frac{\left(\frac{3}{2}\right)}{s^{\frac{3}{2}}}=\frac{q i n}{\Delta} \frac{1}{s}$

Assuming: $y(0)=1$

$Y(s)=\frac{\frac{q i n 1}{\Delta s}-\frac{\sqrt{\pi} \alpha k 1}{2 \Delta} s_{s \frac{3}{2}}^{\frac{3}{2}}+1}{s}$

$Y(s)=\frac{q i n}{\Delta} \frac{1}{s^{2}}-\frac{\sqrt{\pi} \alpha k}{2 \Delta} \frac{1}{s^{\frac{5}{2}}}+\frac{1}{s}$

By applying the inverse Laplace transform to both sides of the relationship (7).

$L^{-1}\{Y(s)\}=\frac{q i n}{\Delta} t-\frac{\sqrt{\pi} \alpha k}{2 \Delta} \frac{\sqrt{t^{3}}}{\frac{3}{4} \sqrt{\pi}}+1$

$h(t)=\frac{q i n}{\Delta} t-\frac{2 \alpha k}{3 \Delta} \sqrt{t^{3}}+1$

The final solution of equation (8) was modelled in MATLAB, as shown in Figure 14.

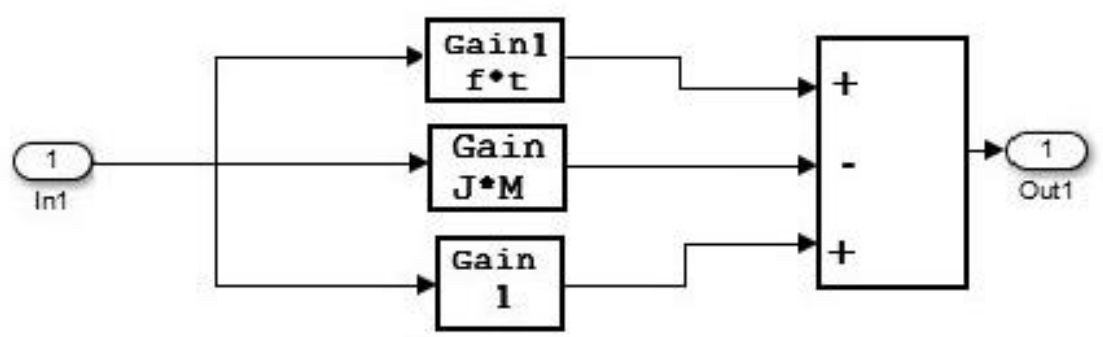

Figure 14. Distributed Time Delay Equation Model Using MATLAB

Both controllers have been tested with a time delay of $0.02 \mathrm{sec}$. Figure 15 shows the result of adjusting the water level in the tank by applying a distributed time delay of 0.02 seconds and using the PID controller for the control process, while Figure 16 shows the result using the FL controllers. 
According to the results, when using the FL controller, the application of the time distributed delay shifted the actual output from the desired value by the amount of applied delay. While, when using the PID controller, it shifted the actual output from the desired value with a little vibration.

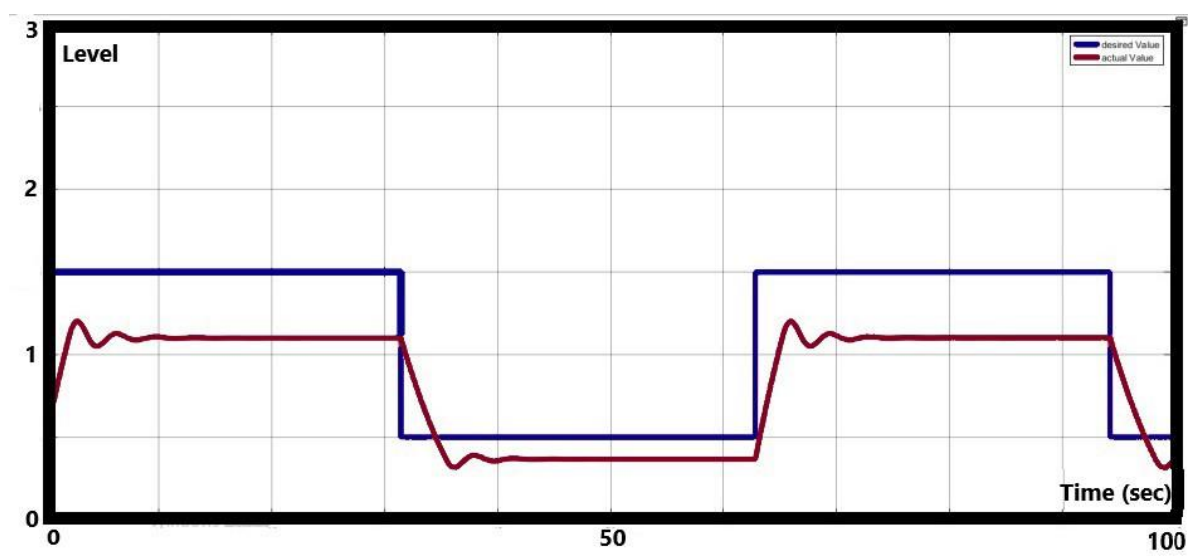

Figure 15. Controlling the water level by using a PID controller and applying a distributed time delay equal to $0.02 \mathrm{~s}$

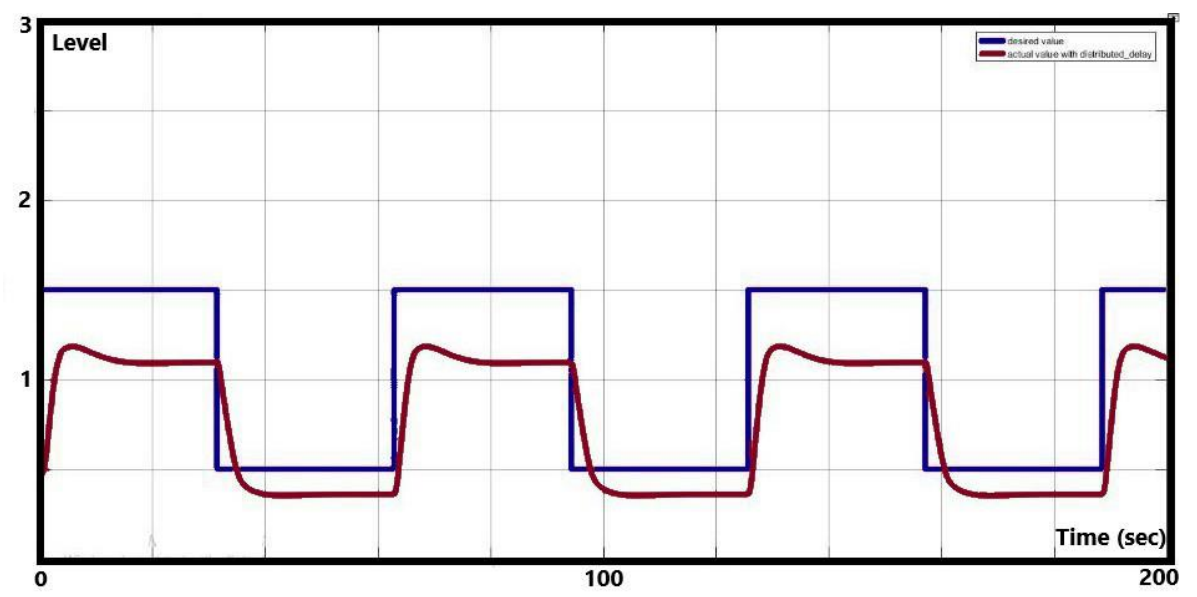

Figure 16. Controlling the water level by using FL controller and applying a distributed time delay equal to $0.02 \mathrm{~s}$

\subsubsection{Discrete-time delay}

The discrete-time delay is a waiting time for the output data equal to $\Delta$ (Beretta and Breda, 2016). It is mathematically formulated as follows:

$$
y(t)=x(t-\Delta)
$$

$\Delta$ : time delay.

To express the time delay in MATLAB, the Delay block is used, and by the Delay Length parameter, the time delay is modified.

Figure 17 shows the result of adjusting the water level in the tank by applying a discrete-time delay of 2 seconds and using the PID controller for the control process, while Figure 18 shows the result using the FL controllers.

According to the results, it was observed that the FL controller produced a stable output signal. Whereas the use of the PID controller resulted in significant vibration in the output signal. This indicates that the more the delay, the worse the result. 


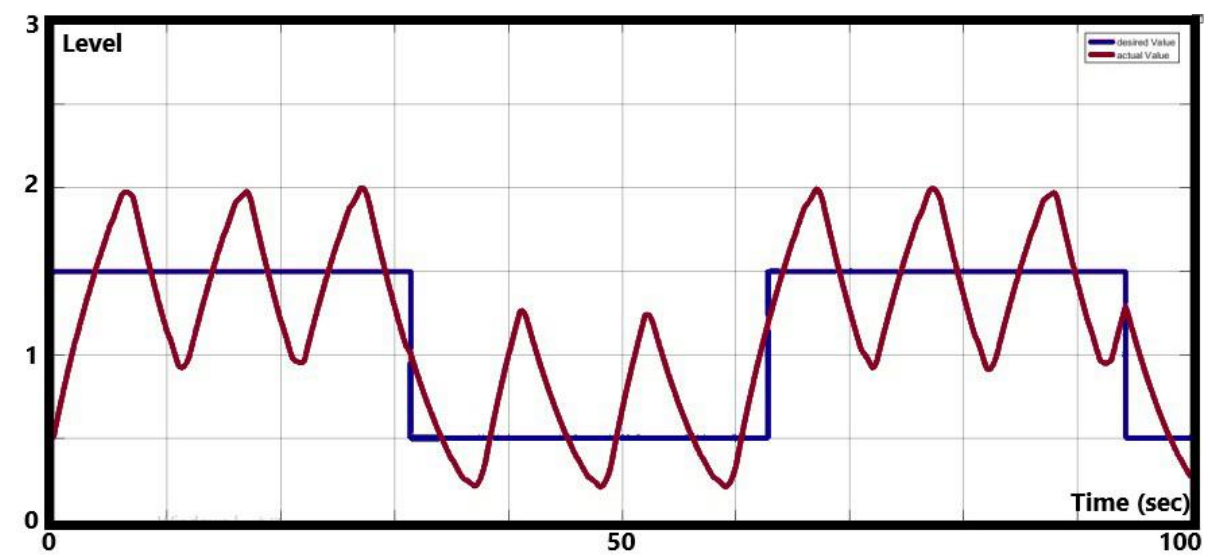

Figure 17. Controlling the water level by using a PID controller and applying a discrete time delay equal to $2 \mathrm{~s}$

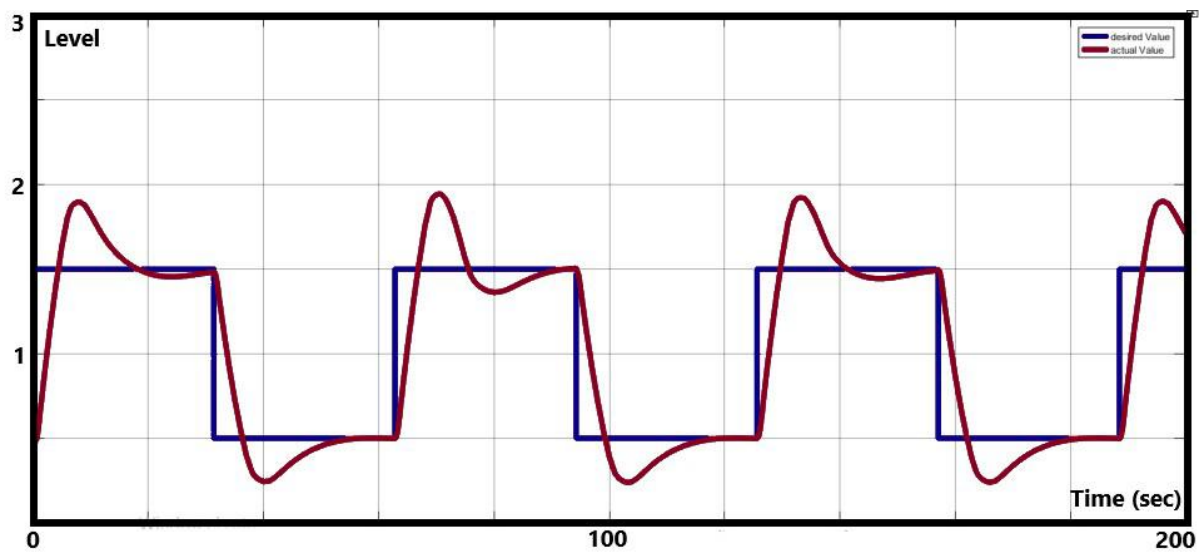

Figure 18. Controlling the water level by using FL controller and applying a distributed time delay equal to $2 \mathrm{~s}$

\section{CONCLUSION}

In this paper, an embedded control system was built in the MATLAB environment to control the water level in a tank. The PID Controller and FL Controller were both tested, and their performance was compared. The first test for the controllers was without applying any time delay, while the second test was by applying two types of time delay: Distributed Time Delay and Discrete-Time Delay. It is concluded from the first test that although the rise time of both controllers was almost the same (about 4 seconds), the FL controller showed higher performance in terms of overshoot and settling time. While the overshoot for the PID controller was 9.33\%, it was eliminated when using the FL controller. Moreover, while the settling time of the PID controller was 10 seconds, it took only 8.6 seconds for the FL controller to stabilize.

The results of the second test, which were applied with a distributed time delay of $0.02 \mathrm{sec}$, showed that with the use of the FL controller, the actual output of the system would change, either slightly increasing or decreasing depending on the value of the delay, meaning that the water level in the tank did not reach the desired level as a result of this delay. Also, with the use of the PID controller, the water level in the tank did not reach the desired level with the presence of vibration in the output signal.

Whereas, with the application of a discrete-time delay of 2 secs, the results showed that both controllers produced vibration in the output signal. When the FL controller is used, the system seeks stability, while with the use of the PID controller, the vibration is large and there is no stability in the tank level. It is concluded that the FL controllers are better than PID controllers in applications where there is a time delay in terms of stability and performance. 


\section{DECLARATION OF INTERESTS}

The author declares that he has no known competing financial interests or personal relationships that could have appeared to influence the work reported in this paper.

\section{REFERENCES}

Al Tahtawi, A. R., \& Marsya, S. Y. B. S. C., 2020, "The Implementation of Embedded Fuzzy Logic Controller on Liquid Level Control System. "In International Seminar of Science and Applied Technology (ISSAT 2020), 161-66. Atlantis Press.

Beretta, E., \& Breda, D., 2016, “Discrete or distributed delay? Effects on stability of population growth. “, Mathematical Biosciences \& Engineering, 13(1), 19.

Boada, B. L., Boada, M. J. L., \& Diaz, V., 2005, "Yaw moment control for vehicle stability in a crosswind“, International journal of vehicle design, 39: 331-48.

Chen, L., 2021, "Principle and Simulation PID Controller of Liquid Level System. ", In Journal of Physics: Conference Series, 012187. IOP Publishing.

Dinesh, C., Manikanta, V. V., Rohini, H. S., \& Prabhu, K. R., 2015, “Real time level control of conical tank and comparison of fuzzy and classical PID controller", Indian Journal of Science and Technology, $8(\mathrm{~S} 2), 40-44$.

Ellis, G. ,2012, “Control system design guide: using your computer to understand and diagnose feedback controllers.", Butterworth-Heinemann.

George, T., \& Ganesan, V., 2020, “Optimal tuning of PID controller in time delay system: a review on various optimization techniques. ", Chemical Product and Process Modeling.

Kamala, N., Thyagarajan, T., \& Renganathan, S., 2012, “Multivariable control of nonlinear process using soft computing techniques. ", Journal of advances in information technology, 3(1), 48-56.

Kumar, S., \& Nagpal, P., 2017, “Comparative Analyisis of P, PI, PID and Fuzzy Logic Controller for Tank Water Level Control System.", International Research Journal of Engineering and Technology (IRJET), 4(4), 1174-1177.

Meshram, P. M., \& Kanojiya, R. G., 2012, “Tuning of PID controller using Ziegler-Nichols method for speed control of DC motor. ", IEEE-international conference on advances in engineering, science and management (ICAESM-2012) (pp. 117-122). IEEE.

Mukhtar, A., Tayal, V. K., \& Singh, H. P., 2019, "Pso optimized pid controller design for the process liquid level control. ", In 2019 3Rd International Conference On Recent Developments In Control, Automation \& Power Engineering (RDCAPE) (pp. 590-593). IEEE.

Muresan, C. I., Birs, I. R., Ionescu, C. M., \& De Keyser, R., 2019, “Tuning of fractional order proportional integral/proportional derivative controllers based on existence conditions. ", Proceedings of the Institution of Mechanical Engineers, Part I: Journal of Systems and Control Engineering, 233(4), 384391.

Perng, J. W., Chen, G. Y., \& Hsieh, S. C., 2014, “Optimal PID controller design based on PSO-RBFNN for wind turbine systems. “, Energies, 7(1), 191-209.

Petkov, P. H., Slavov, T. N., \& Kralev, J. K., 2018, “Design of Embedded Robust Control Systems using MATLAB $® / S i m u l i n k ® ",(V o l .113)$. Control, Robotics and Sensors.

Plerou, A., Vlamou, E., \& Papadopoulos, B., 2016, “Visualization of neuro-fuzzy networks training algorithms: The backpropagation algorithm approach.", Psychology and Mental Health: Concepts, Methodologies, Tools, and Applications (pp. 705-737). IGI Global.

Prusty, S. B., Pati, U. C., \& Mahapatra, K., 2014, "Implementation of fuzzy-PID controller to liquid level system using LabVIEW. ", Proceedings of The 2014 International Conference on Control, Instrumentation, Energy and Communication (CIEC) (pp. 36-40). IEEE.

Shahid, H., Murawwat, S., Ahmed, I., Naseer, S., Fiaz, R., Afzaal, A., \& Rafiq, S., 2016, “Design of a fuzzy logic based controller for fluid level application.", World Journal of Engineering and Technology, $4(3), 469-476$. 
Shaikh, H. M., \& Kulkarni, N. R., 2019, “Perception on PSO, Fuzzy and Fuzzy-PID for Water Level Control of Coupled Tank System. “, 2019 IEEE Pune Section International Conference (PuneCon) (pp. 1-5). IEEE.

Sreepradha, C., Deepa, P., Panda, R. C., Manamali, M., \& Shivakumar, R., 2016, “Synthesis of fuzzy sliding mode controller for liquid level control in spherical tank. ", Cogent Engineering, 3(1), 1222042.

Thakur, A. S., Singh, H., \& Wadhwani, S., 2015, “Designing of fuzzy logic controller for liquid level controlling. ", International Journal of u-and e-Service, Science and Technology, 8(6), 267-276.

Thompson, J. A., Roecker, S., Grunwald, S., \& Owens, P. R., 2012, “Digital soil mapping: Interactions with and applications for hydropedology". Hydropedology, 665-709.

Torres, B. S., De Carvalho, F. B., de Oliveira Fonseca, M., \& Seixas Filho, C., 2006, “Performance assessment of control loops-case studies.", Proc IFAC ADCHEM, Gramado, Brasil.

Yahya, S., Al Tahtawi, A. R., Wijayanto, K., \& Faizah, B. A., 2020, “Liquid Flow Control Design Based on PID-Fuzzy Controller with anti-Windup Compensator. ", 2020 7th International Conference on Information Technology, Computer, and Electrical Engineering (ICITACEE) (pp. 7-12). IEEE.

Yang, S. K., 2012, “A new anti-windup strategy for PID controllers with derivative filters. ", Asian Journal of control, 14(2), 564-571.

Yumurtac1, M., \& Verim, Ö., 2020, “Liquid level control with different control methods based on Matlab/Simulink and Arduino for the control systems lesson.", International Advanced Researches and Engineering Journal, 4(3), 249-254. 